\title{
A Summary of the Marketing Strategies of Luxury Cosmetics Brands
}

\author{
Yangyu Liu ${ }^{1, *}{ }^{*}$ Jiayue $\mathrm{Lu}^{2, \dagger}$ Guanyi $\mathrm{Qi}^{3, \dagger}$
}

\author{
${ }^{1} 710076$ Xi'an, Shan xi Province, China \\ 2310030 Hangzhou, Zhejiang Province, China \\ ${ }^{3}$ CF24 OSP, MSc Business Management, Cardiff University, Cardiff United Kingdom \\ *Corresponding author. Email: qgyvicky9887@outlook.com \\ ${ }^{\dagger}$ These authors contributed equally.
}

\begin{abstract}
With the advent of "appearance level economy", cosmetics, as a consumer product that can quickly improve the overall image, are in an era of large-scale promotion and use. In the context of the new media era and major turning points in society as a whole, how can luxury cosmetics brands use specific marketing strategies to maintain their competitiveness and seek the sustainable development of their brands? Based on this problem, this paper, as a review paper, will be divided into four sections: the introduction of luxury brand beauty, the review of domestic and foreign scholars' research in this field, the summary of previous views and future research prospects. By comparing domestic and foreign literature, this paper summarize the similarities and differences of domestic and foreign research: domestic and foreign literature has both similarities and differences in brand positioning, marketing goals, public participation, promotion methods and other aspects. According to foreign literature, the role of positioning strategy in the cosmetics industry is to positively impact brand loyalty and distinguish itself from other competitors. Based on all the literature, it is concluded that the ultimate goal of luxury cosmetics brands is to improve brand loyalty and brand recognition. Undeniably, most of the literature is based on reasoning, lacking quantitative and theoretical research on large-scale data and evidence from literature from different disciplines. Therefore, researchers can try quantitative research methods and test other theories from different disciplinary backgrounds in the future.
\end{abstract}

Keywords: luxurious cosmetics, marketing, brand positioning, consumer

\section{INTRODUCTION}

With the arrival of the "appearance level economy", cosmetics, as a consumer goods that can rapidly improve the overall image, is in an era of large-scale popularization and use. The continuous enhancement of woman's social status, the expansion of beauty makeup penetration rate, and the improvement of consumption intention are the long-term factors driving the growth of cosmetics consumption. Cosmetics have gradually become one of the six major areas of China's "appearance level economy". In 2019, "makeup" ranked third with a 98.37 heat index, just behind "fitness" and "clothing", which are not far behind.

The cosmetics consumption expenditure in Japan and the United States shows a long-term upward trend. Since the 1980s, with the rise of the industry and the improvement of local cultural confidence, Japanese cosmetics consumption expenditure has continued to increase. Specifically looking at the change of the proportion of cosmetics consumption expenditure of American residents, the period when the proportion increased significantly was the Great Depression period of 1929-1932 (the initial rise of the cosmetics industry), 1936-1945, World War II (more women in the workforce, boosting morale), 1950-1968 (Hollywood stars, television, print media), and the New Economy since 1990 (the Internet accelerated market education).

Compared with developed countries, China's cosmetics market has the fastest growth rate, but the per capita consumption of cosmetics still lags behind that of developed countries. With the improvement of Chinese local cultural confidence, the strengthening of the industrial chain, product upgrading, and the channel and marketing reform, the increase of consumption 
frequency are expected to drive the long-term increase of household expenditure on cosmetics.

Furthermore, the "you create the brand, I contribute" model is well established between luxury goods and cosmetics companies. In March 2020, renowned luxury brand Hermes started making makeup. In fact, it is not the only company heading into the world of cosmetics. Luxury brands starting from leather goods began to focus on beauty makeup product lines in recent years. Prada announced at the end of 2019 that it would launch its makeup in 2021, and it enlisted the help of L 'Oreal, the world's largest cosmetics company.

As a matter of fact, the gross margins on high-end beauty products may be hard to surpass the "windfall" margins on handbags and leather goods. Most luxury handbags make 10-13 times the cost of making them. In other words, gross margins can reach a maximum of around 93\% [1]. As for cosmetics, take L 'Oreal's as an example. Its gross profit margin is only around $73 \%$.

There is no denying that the expansion, acquisitions and promotion of LVMH, which owns brands such as Louis Vuitton, Dior and Tiffany, have made luxury goods, especially bags, as part of the global middle class. However, the very concept of scarcity and limitation of luxury is the antithesis of scale. The core customer base of high-priced personal luxury goods will not expand easily. In addition, as fast-moving consumer good, consumers buy beauty makeup more frequently. For example, cosmetics like lipsticks are easily prone to impulse purchases, but few people can buy Hermes on impulse.

Additionally, starting from beauty and perfume, it is worth noting that luxury goods may also be able to "nurture: young consumers through dream-making beauty products. With their age and purchasing power increasing, these consumers can gradually turn into leather goods and clothing buyers.

Accordingly, in the context of the new media era and the major turning point of the whole society, how do luxury cosmetics brands use specific marketing strategies to maintain their competitiveness and seek a sustainable development of their brands?

By introducing premium cosmetics brands, the Documentary analysis is used to illustrate the marketing mix strategies of luxury cosmetics brands like Dior, YSL, Chanel, and Armani, etc. This report collects and reviews the marketing literature related to high-end cosmetics brands and extracts and sorts out the core content through qualitative analysis methods such as content analysis. Firstly, this paper begins with a literature review at home and abroad from the perspectives of brand positioning, marketing target, promotion strategies, and customer engagement. Then, after sorting out the main marketing strategies of luxury cosmetics brands, an evaluation of the relevant marketing strategies of certain brands will be made. Also, at the end of this paper, some recommendations will be provided for those premium cosmetics brands and making prospects into the future of the cosmetic brand marketing methods.

\section{RETROSPECT OF CHINESE RELATED RESEARCHES IN LUXURIOUS BRANDS OF COSMETICS}

In the spring of 1979, with the formal implementation of China's reform and opening up, the Chinese market began to open to foreign countries. A large number of foreign brands flooded into the domestic market, and luxury brands were no exception. With the rapid development of China's economy, residents' income and consumption levels have risen sharply, and people's desire for luxury goods has also risen sharply. Therefore, in the past two decades, domestic scholars have conducted many investigations and studies on how luxury brands enter the domestic market, determine the target customers, establish the brand image in the hearts of Chinese people, and enhance the brand stickiness reached conclusions. Many experts have conducted interdisciplinary studies between business and psychology based on the psychology of Chinese luxury consumers. Colour makeup line, a line that great part luxury brand has, has also won the academic circle's huge concern likewise.

With regard to the brand positioning, marketing objects, promotion methods and public participation of luxury brands' makeup lines, the four typical luxury brands, Saint Laurent, Lancome, Armani and Chanel are used to carry out a specific analysis through the academic research and analysis of nearly 15 years.

\subsection{Brand Positioning}

Brand positioning is an image of a brand in the mind of consumers. It is not a fixed, static concept. Instead, it is increasingly fluid, often changing from country to country, culture to culture, and in response to specific consumer experiences [2].

First of all, the analysis of brand positioning are divided into two parts: the establishment of brand image in consumers' minds and the transmission of brand culture.

Xing Xiaosan, Brand director of YSL BEAUTY China, said: Since it entered into China in 2013, YSL BEAUTY has adhered to the brand positioning of unrestricted, avant-garde, high-end fashion and full of innovative spirit. YSL BEAUTY hopes to convey a positive, creative and innovative brand image to young consumers [3]. In addition, In terms of the spread of brand culture, He believes that YSL BEAUTY should focus on the product and its value. Wu Sixin, a 
columnist of a financial newspaper, believes that the 12th "Cut male color" and "star lipstick", which are phenomenally popular among young consumer groups, are YSL BEAUTY's brand positioning and successfully create a brand lipstick culture of "passing on both women and men" [4]. Rui Yifang believes that its brand positioning makes consumers feel confident after buying YSL lipsticks [5].

In 1993, Lancome entered the Chinese market. According to The Chinese Medical Beauty magazine, a rose with an unusual fragrance is the brand image of Lancome [6]. Most domestic scholars believe that LANCOME's growth and glory are closely related to the strong and romantic French culture.

In 1998, Armani entered the Chinese market. In The Chinese fashion world, there's a saying that you can't go wrong with an Armani when you don't know what to wear. That statement speaks volumes about Armani's image in the consumer psyche. In 2008, Armani began to enter the Chinese makeup field. Scholar Yin Xiaoxi emphasizes the design of removing all unnecessary decorations and techniques to present the purity and essence of the object closest to the essence, which is the brand positioning of Armani makeup [7]. Liting Fei, an executive at an investment firm, believes that "red" is the image of Armani's beauty brand [8].

In 1993, Chanel officially entered the Chinese mainland. By and large, the establishment of brand positioning of these four brands in the minds of Chinese consumers basically follows the above two steps: establishing brand image and transmitting brand culture. Therefore, based on existing academic studies, the common features of brand positioning of luxury cosmetics brands includes:

It has a brand symbol in the minds of consumers, such as the logo, the outer packaging of a certain explosive item, the brand values and even the appearance of the founder of the brand.

The concept of a high-end atmosphere is given to consumers so that the satisfaction of consumers is higher than the product price.

\subsection{Targeted Market}

Marketing object refers to the enterprise marketing activities of the receptor, that is, the imaginary target customers and influence the audience.

So, what are the characteristics of the marketing objects of luxury cosmetics? Firstly, China's traffic era, which began in 2014, uses idol stars' popularity to drive sales and brand awareness. After determining the time point, this parts analyses the age and characteristics of the marketing target.
Xing Xiaosan, brand director of YSL BEAUTY China, believes that after 2014, Innovative young Chinese consumers (18-28 years old) love to interact with brands and desire to acquire resonance with brands the targeting customers of YSL. In the past, young Chinese consumers would learn from other countries, but now, they have more ideas of their own, the demand for BEAUTY makeup has become higher and higher, and the quality of products is also very high. This is completely different from past consumption characteristics [9].

Armani brand advertising design needs to make precise positioning for different levels of female consumer groups, which can be specifically divided into two age groups. Liting Fei points out that Giorgio Armani Beauty in 2014 divided female consumers into: from 16 to 23 years old, most girls at this stage are students and cannot earn money. Their average monthly living expenses are around 1000-2000 yuan. Although their economic level is limited, they are easily affected by external factors. Between the ages of 24 and 35 , most women are white-collar workers in enterprises and can be regarded as the leading force in purchasing cosmetics. In terms of age, mature women over the age of 30 occupy the first place in the market of Buying Armani [10].

Yanqin $\mathrm{Xu}$ pointed out that Lancome's target consumer group in 2016 is women aged 25-40 with high education and income. Such consumers have a strong desire to buy skincare products and have a high purchasing power. At the same time, their image and temperament are consistent with Lancome's brand image of beauty, dignity and elegance [11].

According to the data, most Chanel Beauty consumers in China belong to the 20-45 age group and have a high income. They are young, rich, and have received higher education. They belong to the group with high education, high quality and high taste. They attach importance to the brand and brand culture and the spiritual enjoyment brought by the brand [12].

Therefore, we find that luxury cosmetics brands have basically broadened the age range of their marketing target after 2014, focusing on young consumer groups. So why do luxury brands do this? In the era when traffic is king, there are countless emerging beauty brands. The old luxury cosmetics should maintain their competitiveness and brand benefits by creating explosive points, such as some makeup items that win the attention of young consumers.

\subsection{Customer Engagement}

Social media and creators are all vying for audience attention, and public engagement builds a relationship with consumers could engage them over the long term. 
According to a large number of literature, the current public participation is mainly concentrated in pop-up stores. A pop-up store is a place that provides a shortterm gathering of consumers according to personalized characteristics. By 2020, there have been more than 3,000 pop-up stores in China, and the current pop-up stores are mainly sales and advertising. The main reason is that shopping needs the guidance of online celebrities. After the e-commerce platform enters a stable stage, it also faces huge promotion costs. Offline experience stores have become a new channel with customer flow and a mode of realization [12].

Pop-up stores are the main sailing ways for famous cosmetics. With the development of the economy, the sales of luxury goods in China are increasing dramatically. Elite groups and young people are the two main consumer groups. The biggest difference between pop-up stores and traditional retail stores is that selling things is not the most important theme. Consumers are more interested in the sense of fun and good-looking experience brought by pop-up stores. The pop-up stores of luxury goods have become a bridge of communication with the public, attracting potential customers to a great extent and enhancing social prestige.

Hui yuan Liu finds Coco Cafe in Shanghai, which is only open for 12 days in 2017. Guests can enjoy coffee on lazy afternoons while experiencing personalized makeup services. However, this is not a pure coffee shop. Chanel Coco Cafe has themed rooms such as "Juice Bar" and "Bubble Bar", which sells perfumes and beauty products.

Research conducted shows that YSL opened a 10hour pop-up shop on a cruise ship at the Shanghai dock on April 15, 2017. YSL seems to be trying to explore human's self-obsession and primitive nature. The biggest selling points of the YSL Beauty club are the limited-edition foundation for its Asian debut and the new Edition for its 25th-anniversary concealer. "It is reported that the foundation in the pop-up store is sold out after opened four hours and the limited edition of the concealer is not sold on the ship, only to provide an experience" [13].

Researchers have announced that compared with traditional retail stores, a major feature of pop-up stores is not to sell goods as the main goal but to add fashion elements, technology. To create a sense of novel and fun experience for consumers, which is more to cater to the preferences of young groups. And makeup itself is deeply concerned by young groups, to create a pop-up shop has become a marketing target of major makeup brands.

To sum up, Pop-up shops are the main form of public participation for high luxury brands
Pop-up stores have a series of advantages such as low cost, low risk, and freshness brought to customers by their timely interactive performance, which can trigger a two-way positive feedback effect between the brand and customer

\subsection{Promotion Strategy}

According to the survey report "2019, New Face of Beauty in China", $86 \%$ of beauty consumers still prefer retail stores. In this context, better connecting the online and offline marketing brands and stimulating consumers' desire to buy is vital.

The promotions are mainly divided into traditional promotions and new media promotions.

There are many traditional ways of promotion, such as celebrity, advertising, retail stores. Data shows that in 2019, 44.8 per cent of new media users in China were experiencing skincare and cosmetics advertisements and beauty products dominated the advertising promotion.

Although advertising industry competition is intense, it at the same time also has huge market potential. Everywhere is full of business opportunities. Traditional marketing strategies are ignoring the initiative of consumers. The intrusion of consumers often accompanies the marketing process and deviates from consumers' real demands to a certain extent. The traditional "participatory marketing" is based on the "realistic" participatory experience, that is, through a series of participatory activities to enhance consumers' goodwill and loyalty to the brand. With the development of virtual technology, brands are increasingly using virtual technology to bring "immersive experiences" to consumers.

With the continuous development of the mobile Internet, online beauty makeup consumption penetration rate has also continued to rise. The habit of online shopping has been formed, and the proportion of online sales of major cosmetics groups has increased significantly. Data show that the penetration rate of online consumption of beauty makeup has exceeded $40 \%$ and is still growing. KOL live with goods, 618 and other large shopping festivals, for consumer sales promotion there are more than buying a gift, giving a series of means such as vouchers, are attracting new customers to shop online.

In the face of such a fragmented, marketing methodology has also changed. The new 4C principle means that the network structure of the Community can be used to connect people and realize the diffusion and dissemination of information quickly by means of the Content or topic with spreading power in a suitable Context, aiming at a specific Community. To achieve effective business communication and value. The Internet can target customers with precision. Social 
networks have a large amount of information about users. By analyzing users' content posted and shared, they can effectively judge users' preferences, consumption habits, purchasing ability, and other information. In this way, through the precise crowd orientation of the target users, the advertising on the network can naturally receive better results than in the traditional network media.

Moreover, the problems of current new media promotion are underestimated. The company's focus on short video promotion can bring certain dividends, but it needs a more refined operation in the increasingly fierce market competition. Once the advertisement is placed too much, it may bring some negative emotions to consumers. Therefore, companies must collect user suggestions and feedback and extend the product life cycle with product iterations that address users' pain points. The cooperation with KOL can not only be regarded as a business, but they are also deep users of various products, and their suggestions and jokes on the brand are more worthy of reference [14].

To sum up, to cater to the development of the new media era like the young consumer groups who love online shopping. For the rapid development of more and more close to online shopping and video publicity. The Nielsen study found that traditional beauty marketing contact with over-the-counter salespeople still positively affects beauty and care store shoppers. Therefore, the demand for online drainage from offline stores exists for a long time for the beauty makeup retail industry. The two promotions should be carried out together to complement each other's advantages.

\section{RETROSPECT OF FOREIGN-RELATED RESEARCHES IN LUXURIOUS BRANDS OF COSMETICS}

\subsection{Brand Poisoning}

The early concept of positioning, defined by Trout and Ries, literally means the position generated in the prospect's mind through the product and the company image. Later Trout and RIes expanded the meaning of positioning, which refers to a communication system in people's minds at the right time and right circumstances [15]. In marketing, positioning is considered a tool of everyday marketing activities, resulting in the successful creation of a customer-focused value proposition, which directly leads the brand's target consumer to buy the product. Therefore, if a brand has a strong position, it can successfully improve its brand awareness and gain competitive advantages over its competitors.

As the representatives of high-end cosmetics, Christian Dior, Chanel, YSL, and Giorgio Armani have different brand positioning strategies. Perceived as a prestige brand, Christian Dior focuses on the different images of femininity, especially in the perfume sector. Miss Dior represents a "modern princess" with high social standing; Poison creates an image of a female devil with lethal power, and Addict stands for addiction and dependence [16]. With its unique name, design, and symbol, Chanel builds a style of simplicity and elegance, which differentiates the products from others. Although YSL is usually purchased with mid-end brands in terms of price, according to the survey of women in the United States interested in beauty and cosmetics, $71 \%$ of women view YSL as a luxurious brand. YSL beauty positions itself as an innovative brand with heritage by the spread of pop-up stores and leaning into Yves, the designer [17] to conquer the luxury makeup market. Giorgio Armani said, "remain true to yourself and your philosophy" as a guideline to the whole brand. Therefore, the brand position managed by Giorgio Armani associates with fashion, style, and products of high quality, delivered by the design, brand ambassador, and the story of its founders [18].

Additionally, in the global beauty industry, those companies also use CSR related activities and technologies to enrich their brand image. For example, Chanel distributed a public booklet about the approach to protecting nature and launched a project to preserve natural resources in 2010 [19]. Partnership with Green Cross International, Armani's charity project, Acqua for life, aims to provide safe drinking water to the countries in need [20]. According to the theory of He and Lai, CSR activities are the mediating role of brand positioning, which have both functional and symbolic images to strengthen brand loyalty [21]. As part of the positioning strategy, creativity and technologies are key elements to distinguish the brand characteristics from long term prospects. The emphasis on technology in Chanel's product stresses the makeup technology of quality products, and mirror stands in shops by smartly using light, ceiling light in stores to optimize the colour and texture of its products, and the mirrors with light adjustment function [22].

To highlight the unique attributes, companies like Christian Dior, Chanel, YSL, and Giorgio Armani generally convey the brand characteristics to their consumers in product design, corporate concept, and the story of its founder. The CSR related activities and innovative technologies are also integrated into the whole brand image. The effect of positioning strategy in the cosmetic industry is to positively influence brand loyalty and differentiate itself from other competitors.

\section{2 target market}

According to Pride, Hughes, and Kapoor's theory in the Foundations of Business, a target market is a group of consumers with similar characteristics (like age, gender, income level, or lifestyle), for which an 
organisation or business market tailors to their need to implement a marketing mix strategy. Normally, the target markets tend to be the most profitable segments for the company. Numerous studies have explored the motives for buying luxury brands, and findings consistently confirm that the target market of luxury cosmetics brands has similar characteristics.

By contrasting luxury brands with value brands, Hagtvedt and Patrict show that the luxury brands have greater extendibility than the value brands. The promise of pleasure (hedonic potential) potentially plays as a key driver of brand extendibility [23]. McFerran, Aquino, and Tracy also included pride as a potential motive for luxury products. A sense of accomplishment promotes consumers to purchase from luxury brands, and the behaviour signals arrogance to others. A crosscultural study conducted by Bian and Forsythe examines the purchase intentions for luxury goods between the U.S and Chinese consumers. And the study shows that the social-function attitudes positively influence the U.S and Chinese consumers' purchase intentions. The desire for fashion lifestyles shows consistency in consumers from both countries.

Using customers' purchase intention, luxury cosmetics brands such as YSL and Dior have set up corresponding target markets according to their own brand positioning. Fashion trend summarizes the customer profile of Dior [24]. The result shows that Dior's customers mainly focus on megacities in America, Asia- Pacific, and European countries. The demographic segmentation is high income and high education background female aged 25-50, normally with professional or manager-level jobs. Kaushik pointed out that the target audience of YSL beauty is 18-35 aged women who are trendy, urban, and digital make-up and beauty addicts [25]. As an icon and a legend in the fashion industry, Chanel uses a mix of demographic and psychographic segmentation strategies to set its target market. Women in the age group of 15-40 incline fashionable accessories. Similarly, the target market of Giorgio Armani includes celebrities, high-earning individuals and business class, and the age group sets between 35-50 [26]. Overall, these luxury brands are mainly aimed at high-income women aged 20-50, and the consumer group of YSL is relatively younger.

Table 1. The target market of Dior, YSL, Chanel, and Armani

\begin{tabular}{lllll}
\hline Brand & Dior & YSL & Chanel & Armani \\
\hline Age group & $25-50$ & $18-35$ & $15-40$ & $35-50$ \\
Characteris & High income, & Trend: & An & Celebrities \\
es & High education & urban, & inclination & High-earning \\
& background, & digital & towards & individuals \\
& Professional job, & make- & fashionable & Business-class \\
& Manager level & up, & accessories. & \\
& job, & beauty & & \\
& Megacities & addicts' & & \\
& & women. & & \\
& & & \\
& & & \\
& & & \\
& & & \\
& & &
\end{tabular}

Additionally, Degen analysed the opportunity for luxury brands in China. Due to the large scale of the Chinese market, to gain more market share and be successful, international luxury brands must win in China. And according to Hedrick-Wong, the affluent Chinese consumers are all 'nouveau riche' [27]. The reason lies between the Confucian values, the growing influence of Western values. Since the branded luxury brands like Dior and Chanel show a marked fascination to Chinese consumers, those products could prove their social status and success.

Therefore, the research shows that for Dior, Armani, Chanel and YSL, there are certain commonalities in customers' purchase intention, customers' Consumption Motivation and target market characteristics. Combined with a study conducted by Pholvisrethkul, there is a 0.01 significant level relationship between marketing mix elements and consumer attitude [28]. Consequently, these luxury cosmetics brands have causality in their brand positioning, target customers and even marketing mix strategies.

\subsection{Promotion Strategy}

After establishing the brand positioning and selecting the target market, the luxury cosmetics brands need to use various methods to convey appropriate information to customers to increase brand awareness and generate sales. According to E. Jerome McCarthy, who proposed the concept of the 4Ps marketing mix strategies, promotion is a form of marketing communication with the target audiences. For luxury cosmetics brands, using appropriate promotion means is one of the key strategies to maintain high-end positioning and continuously improve customer recognition. The literature largely summarized the most common promotion methods: establish brand loyalty, content marketing, and influence marketing.

Parmar mainly studied how cosmetics brands improve brand loyalty in the Y-generation group. Ygeneration (or Millennials) is style and fashion dominated and is the main purchase group of luxury cosmetics products. Parmar stated that their buying behaviour is influenced by friends, parents, and excellent quality, contributing to building brand loyalty. Meanwhile, there is no significant correlation between consumers' gender and domiciles with their loyalty to cosmetics brands. Using reference group theory and social adaption theory, Löfgren and Li illustrated that celebrity endorsement plays a vital role in transferring the meaning of cosmetics advertising [29]. They also stated that the brand loyalty of luxury cosmetics includes behavioural loyalty and attitudinal loyalty. And the purchase behaviour of consumers does not necessarily lead to attitudinal loyalty. Chan's research studied the determinants of brand loyalty in Malaysia [30]. Brand image, perceived quality, and price 
significantly correlate with consumers' brand loyalty towards cosmetic products. Moreover, brand experience has a significant impact on brand loyalty. And according to the studying of Yousaf et al., brand credibility, brand awareness, brand association, and product quality directly influence brand loyalty as well.

Content marketing, a well-known marketing strategy adopted by beauty brands, describes a partnership between luxury cosmetics brands and digital influencers to inform customers to be aware and buy their products. Figueiredo illustrated the advantages of content marketing [31]. Communicating with customers is the key to the success of cosmetics brands. Content marketing creates a win-win situation for both luxury cosmetics brands and digital influencers, where the digital influencers create interesting and original content, and the beauty brands promote their products. Advertising campaign hashtags is a common method of content marketing. Kim and Phua stated that luxury brand's consumers show a positive attitude toward empowerment campaign hashtags, which stands for positive self-image social identities [32]. The study of Afifah focuses on the relationship between different contents of beauty vloggers and customers' purchase intentions. Study shows that the beauty vlogger content directly influences the brand image and builds consumer perceptions of beauty products. However, the information conveys by the vloggers could not directly affect the purchase intentions of the beauty products.

Influence marketing shows the important role of the Internet in promotion strategies. Voltolini found that social media like Instagram has had a huge impact on the purchase intentions of the Millennial generation [33]. Those social media influencers are ideal channels to create, share, promote, and engage the brand's information with its target audiences. Although most audiences are aware of the commercial relationship between the brands and influences, customers' purchase decisions could not be negatively affected. Paço and Oliveira also stated that the influence of marketing could spread the new fashions and trends of beauty products, which could impact customers' attitudes, behaviours, and purchase intentions. In the luxury cosmetic industry study, Yousaf et al. demonstrated that the impacts of advertisement content are creating awareness and perception, influencing consumer's buying motives, changing buying behaviour, and generating new market creation [34]. Cosmetic companies commonly use TVCs and billboards as their marketing departments.

\subsection{Customer Engagement}

Customer engagement refers to a voluntary interaction between customers and an organization (or brand), applies to online and offline participation. For luxury cosmetics products, online participation and offline participation are all very common customer engagement strategies. However, a large number of literatures show that online participation is a more frequently used customer engagement strategy for beauty brands.

The research on the online engagement strategy of luxury cosmetics brands mainly focuses on social media, social influencers, and communication content. Shen and Bissell examined the different means of social media engagement strategies [35]. Study shows that as an important role in building strong brands, viral marketing (or viral advertising) spreads the original message about the brand's product and services via interaction between consumers and relevant users. As for the specific type of interaction, most of the high-end brands would use posed open-ended questions, and the time feature is today $>$ future $>$ past $>$ tomorrow, which means beauty brands prefer to pose something happening today. To be more specific, Facebook is a perfect channel to connect brands and consumers. Oliveira also stated that social media contributes to boosting brand awareness [36]. Facebook is the most commonly used platform, and Instagram is getting increasingly popular. However, more social media interactions do not determine a better relationship with consumers for beauty brands.

By building up their own followers, social media influencers have emerged to showcase products, conduct online product reviews, and post lifestyle. Jensen studied the influencer marketing strategy of beauty brands in Norway [37]. The exploratory study found that consumers are more receptive to marketing messages instead of communicating with brands directly. And there are four components to a successful influencer marketing campaign: engagement, credibility, inspiration, and storytelling. Chaves conducted an online survey to investigate the impact of influencer marketing on consumers' value perceptions and purchase intention on luxury beauty brands [38]. The result shows that the congruence between the social media influencers and premium beauty brands significantly impacts consumers' value perceptions and purchase intentions. And luxury cosmetics brands have four specific value perceptions: trustworthiness, high quality, prestige, and exclusiveness. Therefore, a capable social media influencer of premium beauty brands should fit brand imagery.

As for communication content, Nouis highlighted the benefits of using consumers' content for luxury beauty brands, especially the organic Word-of-Mouth (eWOM) [39]. Social media users frequently share experiential content about beauty brands functionality and authenticity, and content is an incentive for customer engagement strategy. Cao makes a speciality of the characteristics of the communication content of beauty brands on China's social media Sina Weibo [40]. 
Cao viewed social media as an important marketing practice to generate market attention. More importantly, video post is the most popular media type, and celebrities are a useful way to engage with online users. Incentive posts, giveaway incentive content, news information, show entertainment content, and feedback interaction are all effective, engaging strategies.

There are few studies on offline participation in the literature. But in recent years, major luxury makeup brands have gradually expanded the way of offline participation. Chanel established Customer Relationship Management (CRM) to handle customer relationships in 2016. The brand makes optimal use of beauty advisors (BA) to help consumers to find the most suitable products for their skin. Moreover, the pop-up store is a highly important channel for a luxury cosmetics company to strengthen its public relations. YSL beauty opened a two-day "Beauty Hotel" in Paris in 2018, with five floors of immersive and interactive experiences like fragrance workshops and rooftop terrace café [20]. According to WWD, the beautiful hotel in Paris generated 2,000 social media posts and 1.4 million engagements, with an overall reach of 160 million on social media.

\section{CONCLUSION AND SUGGESTIONS FOR FUTURE RESEARCH}

\subsection{Conclusion and shortcomings}

The literature highlights how the marketing strategies are applied in luxury beauty products while raising even more questions. Future research should continue to test different theories in the luxury context. Domestic and foreign literature has similarities and differences in the aspects of brand positioning, marketing targets, public participation, and promotion methods.

Foreign literature believes that the effect of positioning strategy in the cosmetic industry is to positively influence brand loyalty and differentiate itself from other competitors. In addition to emphasizing their high-end positioning, luxury brands also do charity activities to show their corporate social responsibility. Moreover, although the brand's target groups are very similar in age groups, there are similarities and differences in characteristics. Domestic scholars believe that Brand positioning is in response to specific consumer experiences. It is not a fixed, static concept.

In addition, domestic and foreign scholars believe that the target market of luxury cosmetics brands has similar characteristics. Luxury cosmetics brands have causality in their brand positioning, target customers and even marketing mix strategies. The media play a huge role in the brand image, and symbolic image has more effect than the functional image on brand loyalty.
Both functional and symbolic images had positive influences on brand loyalty.

Furthermore, foreign literature has already done plenty of study for luxury cosmetics products. Online participation and offline participation are all very common customer engagement strategies. However, a large number of literatures show that online participation is a more frequently used customer engagement strategy for beauty brands. But in the domestic study, it is found that more documentaries about offline customers engagements compared with online selling. According to a large number of literatures, the current public participation is mainly concentrated in pop-up stores.

Also, in terms of a promotion strategy, content marketing is a useful method adopted by Beauty Brands, which evolved from a more traditional marketing strategy. Also, communication is key when it comes to digital marketing. The literature largely summarized the most common promotion methods by establishing brand loyalty, content marketing, and influence marketing. And the foreign literature deems that creative advertisement and celebrity marketing do not greatly affect the buying behaviour of youth. Moreover, beauty vlogger content influences the brand image of beauty products but does not affect purchase intentions.

All in all, combined with domestic and foreign literature and related analysis, this paper draws the following three conclusions:

(1) To strengthen the high-end attribute of the brand, the marketing strategy of luxury cosmetics brands should highlight the four perspectives of brand positioning, target market, marketing strategy and customer participation.

(2) The marketing position of beauty brands should be consistent with the target market.

(3) Luxury beauty brands should increase communication channels with customers. Whether it is content marketing or impact marketing, brands need to increase brand awareness through effective interaction.

Whether domestic or foreign literature, documentary analysis and content analysis are the main methods to study the different marketing strategies of luxury cosmetic brands. In the research of content analysis, researchers mainly start from the following three perspectives. Firstly, researchers summarize and compare the similarities and differences between luxury beauty brands represented by Christian Dior, Chanel, YSL, and Giorgio Armani and mass beauty brands like MAC and Cover Girl in four levels: brand positioning, target customers, promotion strategy and customer engagement. Secondly, from consumers' perspective, the researchers explore the impact of different 
marketing strategies of beauty brands on consumers' purchase intention. Thirdly, through the introduction of sociological theory like reference group theory and the social adaptation theory, the researchers also explore the applicability of different age groups of consumers to different marketing strategies and how beauty brands should catch customers' attention. In addition to content analysis, the quantitative analysis provides important evidence for studying the marketing strategy of luxury cosmetics brands. In the process of quantitative analysis, the domestic and foreign literature is mainly studied through questionnaire survey and hypothesis test analysis. The researchers set up questionnaires according to different research questions and selected appropriate participants to complete the questionnaire. At the same time, the researchers set relevant hypotheses according to the theoretical basis and choose to accept or reject the null hypothesis based on the survey results.

In terms of research methods, documentary analysis and content analysis are mainly used in the qualitative analysis of the marketing strategy of luxury cosmetics brands in domestic and foreign literature, and questionnaire survey and data analysis are mainly used in the quantitative analysis. Generally speaking, the combination of quantitative analysis and qualitative analysis is a more comprehensive research method. However, there is relatively little research on quantitative analysis in both domestic and foreign literature. Moreover, in quantitative analysis, a large enough sample size is one of the important factors to ensure the effectiveness of data. In some literatures, it is found that the sample size of some questionnaires is limited. The respondents often come from a specific city or region, and the sample size is only about 100200. For the research on the marketing strategy of luxury cosmetics brands, consumers' age, country, gender, education, and income level are all very important factors. Unfortunately, there is a lack of quantitative research that comprehensively considers all the above factors. Similarly, in qualitative analysis, researchers' research mainly focuses on the effect of various marketing strategies and their impact on consumers. Consumer behaviour is closely related to consumers' psychology in a specific social background. At present, in the qualitative analysis of domestic and foreign research, there is a lack of marketing strategies for various luxury makeup brands from the perspective of psychology and sociology.

\subsection{Suggestions for Future Research}

Firstly, from the perspective of research methods, the domestic and foreign should combine quantitative research and qualitative research. In quantitative research, researchers should expand the sample size, considering the age, country, gender, education and income level of the sample. And these factors can be divided into different dimensions to explore the relationship between these different dimensions and different marketing strategies. In qualitative analysis, the domestic and foreign literature has been relatively comprehensive. However, from the perspective of research, the marketing strategy of luxury cosmetics brands in the future can be cut in more from the perspective of sociology and psychology.

Then this paper also makes some recommendations for luxury cosmetic brands in marketing strategy. In terms of brand positioning, beauty brands should establish appropriate positioning distinguished from other brands and can express the diversity of brand styles through different types of products. Meanwhile, the brand's corporate social responsibility (CSR) is also an important way to establish a good brand image. From the perspective of marketing objects, luxury cosmetics brands should accurately grasp the characteristics of their own brand audience and formulate appropriate marketing mix strategies according to the characteristics and background of consumers. More importantly, the main job of major beauty brands is to boost the purchase intention of their marketing targets. For customer engagement, major luxury cosmetics brands should make good use of social media influencers. And the four key components of a successful influencer marketing campaign are engagement, credibility, inspiration, and storytelling. Therefore, it is vitally important to ensure consumers are receptive to marketing messages from different customer engagement strategies. Lastly, whether it is content marketing, word-of-mouth marketing or influencer marketing, the ultimate goal of the luxury cosmetic brand is to improve brand loyalty and brand awareness. Thus, due to the special positioning of the luxury market, different from the mass market, luxury cosmetics brands should advocate for consumers' positive self-image social identities.

\section{REFERENCES}

[1] Liu, J., 2021. Souhu. [online] Sohu.com. Available at: <https://www.sohu.com/a/225146215_40976> [Accessed 17 August 2021].

[2] Wunker, S., Light, L., Wunker, S., Wunker, S. and Smith, S., 2021. Brand Strategy | Branding Strategy Insider. Available at: <https://www.brandingstrategyinsider.com/> [Accessed 17 August 2021].

[3] Han, J., 2019. Marketing China. Beijing Business Management Cadre Institute.

[4] Wu, S., 2018. "Out of stock king" YSL makeup how to become a phenomenon level burst red brand. Cosmetics finance online. 
[5] 2016. Business Management Review. China Business Publishing House.

[6] 2001. Medical Aesthetics and Cosmetology. Medical Beauty Magazine.

[7] Yin, X., 2013. The Combination of Structure and Culture-Armani. Architecture \& Culture, p.1.

[8] Fei, L., 2014. The Analysis of Women Consuming Psychology in Cosmetics-Armani. Henan Literature and Art Publishing House, p.3.

[9] Han, J., 2019. Marketing China. Beijing Business Management Cadre Institute.

[10] Fei, L., 2014. The Analysis of Women Consuming Psychology in Cosmetics-Armani. Henan Literature and Art Publishing House, p.5.

[11] Xu, Y., 2016. Marketing strategy of virtual community of Cosmetics brand in China Lancome Rose Community. Tianjin Enterprise Federation, p.6.

[12] Baidu Wenku, 2021. Chanel Market Segmentation. p.3.

[13] Chinese Internet Data Research and Information Center -199IT, Sheng., 2021. R3: Q3 2016 Chinese luxury, beauty makeup and industry insight reports (download) attached it || Internet data information network - 199 Chinese Internet data research information center - 199 it.[online] 199it.com. Available at: <http://www.199it.com/archives/515626.html> [Accessed 17 August 2021].

[14] Yang, B., 2021. Sohu. [online] Sohu.com. Available <https://www.sohu.com/a/390263582_146342, 7/20/2021> [Accessed 17 August 2021].

[15] Ries, A. and Trout, J. 2001. Positioning: The Battle for Your Mind. Available at: https://prolightinggroup.com/wpcontent/uploads/2020/08/Positioning_-The-Battlefor-Your-Mind.pdf [Accessed: 5 July 2021].

[16] Celhay, F. and Magnier, L. 2017. Representations of women and brand positioning at Christian Dior. Available at: https://www.researchgate.net/publication/3206208 07_Representations_of_women_and_brand_positio ning_at_Christian_Dior [Accessed: 13 July 2021].

[17] Sandler, E. 2018. How YSL Beauty plans to conquer the luxury makeup market - Glossy. Available at: https://www.glossy.co/evolution-ofluxury/how-ysl-beauty-plans-to-conquer-theluxury-makeup-market/ [Accessed: 3 August 2021].
[18] Saviolo, S. 2002. BRAND AND IDENTITY MANAGEMENT IN FASHION COMPANIES. Available http://www3.sympatico.ca/synergy1/Armani.pdf [Accessed: 3 August 2021].

[19] Nagasawa, S. and Kizu, Y. 2012. Green Action as a Luxury Strategy in the Field of Cosmetics. In: International Marketing Trends Conference. Venice: WASEDA BUSINESS \& ECONOMIC STUDIES

[20] Brand New. 2017. GIORGIO ARMANI - brand differentiation and positioning. Available at: http://brandnewuctbdm.blogspot.com/2017/11/gior gio-armani-brand-differentiation.html [Accessed: 1 August 2021].

[21] He, Y. and Lai, K. 2012. The effect of corporate social responsibility on brand loyalty: the mediating role of brand image. Total Quality Management \& Business Excellence 25(3-4), pp. 249-263. doi: 10.1080/14783363.2012.661138.

[22] Nagasawa, S. and Irisawa, Y. 2013. Luxury Strategy of Beauty Products by Chanel. In: International Marketing Trend Conference 2013. Available at: http://www.marketing-trendscongress.com/paper/luxurystrategy-beautyproductschanel [Accessed: 11 July 2021].

[23] Hagtvedt, H. and Patrick, V. 2009. The broad embrace of luxury: Hedonic potential as a driver of brand extendibility. Journal of Consumer Psychology 19(4), pp. 608-618. doi: 10.1016/j.jcps.2009.05.007.

[24] Chang, V. 2017. Chosen Brand Consumer and Brand Profile: Dior customer profile. Available at: https://culcvickychang.wordpress.com/2017/06/16/ dior-customer-profile/ [Accessed: 2 August 2021].

[25] Kaushik, M. 2018. YSL AND MILLENNIALS. Available at: https://scentsationalbrands.wordpress.com/2018/12 /07/ysl-and-millennials/ [Accessed: 4 August 2021].

[26] Bhasin, H. 2018. Marketing Strategy of Chanel Chanel Marketing Strategy. Available at: https://www.marketing91.com/marketing-strategychanel/ [Accessed: 2 August 2021].

[27] Wong, Y. and Sekulic, A. 2007. Succeeding like success: The affluent consumer of Asia.

[28] Pholvisrethkul, T. 2002. A COMPARATIVE STUDY OF CONSUMER BEHAVIOR AND ATTITUDE TOWARDS LANCOME AND SHISEIDO. Master, Assumption University. 
[29] Löfgren, E. and Li, J. 2010. Brand Loyalty- A Study of the Prevalent Usage of Celebrity Endorsement in Cosmetics Advertising. Master, Umeå School of Business.

[30] Mansori, S. 2016. Factor that influences consumers' brand loyalty towards cosmetic products. Journal of Marketing Management and Consumer Behavior 1(1)

[31] Figueiredo, S. 2018. CONTENT MARKETING AND BEAUTY AND COSMETIC BRANDS' STRATEGY. Master, ISCTE Business School.

[32] Kim, T. and Phua, J. 2020. Effects of Brand Name versus Empowerment Advertising Campaign Hashtags in Branded Instagram Posts of Luxury versus Mass-Market Brands. Journal of Interactive Advertising 20(2), pp. 95-110. doi: $10.1080 / 15252019.2020 .1734120$.

[33] Voltolini, E. 2021. How Instagram has changed the way in which women from the Millennial generation in Ireland are influenced by beauty brands for purchasing decision.. Master, National College of Ireland.

[34] Fatima, S. and Lodhi, S. 2015. Impact of Advertisement on Buying Behaviours of the consumers: Study of Cosmetic Industry in Karachi City. nternational Journal of Management Sciences and Business Research 4(10), pp. 125-137.

[35] Shen, B. and Bissell, K. 2013. Social Media, Social Me: A Content Analysis of Beauty Companies' Use of Facebook in Marketing and Branding. Journal of Promotion Management 19(5), pp. 629651. doi: 10.1080/10496491.2013.829160.

[36] Oliveira, R. 2016. SOCIAL MEDIA ENGAGEMENT IN THE BEAUTY SECTOR IN PORTUGAL COMPARING BEAUTY OPINION LEADERS WITH BEAUTY BRANDS?. Master, Nova School of Business and Economics.

[37] Jensen, L. 2018. An exploratory study of how Influencer Marketing is used by beauty brands in Norway. Available https://nordopen.nord.no/nordxmlui/bitstream/handle/11250/2567673/L.Jensen.p df? sequence $=1$ [Accessed: 3 August 2021].

[38] Dogra, K. 2019. The impact of influencer marketing on brand loyalty towards luxury cosmetics brands: Comparison of Generation Z and Millennial. Master, Modul Vienna University.

[39] Nouis, M. 2020. Manufactured Authenticity: How Beauty Brands Use Consumers' Content to Communicate Branding Messages. Master, Örebro University.
[40] Cao, M. 2017. A Content Analysis of Beauty Brands' Use in China of Sina Weibo to Improve Marketing and Customer Engagement. Master, the School of Arts and Communication at Florida Institute of Technology. 